\title{
Antibiotic Susceptibilities and Serotyping of Clinical Streptococcus Agalactiae Isolates
}

\author{
Altay Atalay, Mehmet Ölçü, Duygu Perçin
}

Department of Medical Microbiology, Faculty of Medicine, Erciyes University, Kayseri, Turkey

\begin{abstract}
Objective: Streptococcus agalactiae (Group B streptococci, GBS) are frequently responsible for sepsis and meningitis seen in the early weeks of life. GBS may cause perinatal infection and premature birth in pregnant women. The aim of this study was to serotype GBS strains isolated from clinical samples and evaluate their serotype distribution according to their susceptibilities to antibiotics and isolation sites.

Material and Methods: One hundred thirty one S. agalactiae strains isolated from the clinical samples were included in the study. Of the strains, 99 were isolated from urine, 20 from soft tissue, 10 from blood and 2 from vaginal swab. Penicillin $G$ and ceftriaxone susceptibilities of GBS were determined by the agar dilution method. Susceptibilities to erythromycin, clindamycin, vancomycin and tetracycline were determined by the Kirby-Bauer method according to CLSI criteria. Serotyping was performed using the latex aglutination method using specific antisera (la, Ib, II-VIII).
\end{abstract}

Results: While in 131 GBS strains, serotypes VII and VIII were not detected, the most frequently isolated serotypes were types la (36\%), III (30.5\%) and II (13\%) respectively. Serotype la was the most frequently seen serotype in all samples. All GBS isolates were susceptible to penicilin G, ceftriaxone and vancomycin. Among the strains, tetracycline, erythromycin and clindamycin resistance rates were determined as $90 \%$, $14.5 \%$, and $13 \%$ respectively.

Conclusion: Penicillin is still the first choice of treatment for the infections with all serotypes of S. agalactiae in Turkey.

Key Words: Streptococcus agalactiae, antibiotic susceptibility, serotype

Received: 09.03.2010 Accepted: 17.08.2010

\section{Introduction}

Infections due to Group B Streptococci (GBS) have frequently been seen since 1970s, especially in developed countries. GBS are usually responsible for sepsis and meningitis in the first weeks of life. In spite of regional variations, the incidence for GBS-related neonatal meningitis and sepsis is 0.5-3 per 1000 live births (1). These microorganisms can commonly colonize in the genital and gastrointestinal system in adults. However, in pregnant women, it can cause perinatal transmission and preterm labor (2). The incidence of invasive GBS infection in non-pregnant adults has increased four-fold recently up to 4.1-7.2 per 100.000. Nine capsular polysaccharide serotypes have been recognized so far: Serotype la, Ib, II-VIII. GBS are sensitive to penicillin, and penicillin should be the first choice of treatment following diagnosis. The resistance rates to clindamycin and erythromycin is increasing amongst the strains (3).

The aim of this study was to define the serotypes and the relationship between the serotype, isolation site and antibiotic susceptibility of $S$. agalactiae strains isolated from various clinical specimens.

\section{Material and Methods}

The study included $131 \mathrm{~S}$. agalactiae strains isolated from the clinical specimens, which were sent to the Bacteriology Laboratory of the Hospital of Erciyes University, Faculty of Medicine and identified by the CAMP test, hippurate hydrolysis and latex agglutination test (Omega, UK). The strains were stored at $-20^{\circ} \mathrm{C}$ in skimmed milk (Oxoid, UK) until the date of the study.

Serotype identification was performed using the latex agglutination method with the Strep-B-Latex kit (Statens Serum Institut, Denmark).

The susceptibilities of GBS for penicillin G and ceftriaxone were studied using the agar dilution method with the recommendations of the CLSI (4). The susceptibilities of the strains to erythromycin, clindamycin, tetracycline and vancomycin were studied and evaluated by the Kirby-Bauer disk diffusion method according to the recommendations of CLSI (5). The phenotypes for macrolide resistance were studied using the D-test method. In the D-test, disks containing erythromycin $(15 \mu \mathrm{g})$ and clindamcyin $(2 \mu \mathrm{g})$ were placed 15 to $20 \mathrm{~mm}$ apart on an agar plate that had been inoculated with the clinical 
isolate. The formation of a "D"-shaped zone around the clindamycin disk was interpreted as "inducible $\mathrm{MLS}_{B}$ "; the formation of a normal zone of sensitivity was interpreted as "efflux", and the formation of a normal zone of resistance as "constitutional $\mathrm{MLS}_{B}{ }^{\prime \prime}$ (6). S. pneumoniae (ATCC 49619) was used as the quality control strain.

\section{Results}

Of the $131 \mathrm{~S}$. agalactiae strains, $99(75.6 \%)$ were isolated from the urine, 20 (15.3\%) from the wound, 10 (7.6\%) from blood, and 2 (1.5\%) from vaginal swab specimens. The serotypes of the strains are presented in Table 1. There was no serotype VII or VIII. The most common serotypes were serotype la (36\%), serotype III (30.5\%) and serotype II (13\%), respectively. As seen in Table 1, while serotype III could not be found in specimens except the blood culture, almost $40 \%$ of the isolated ones from the urine culture were serotype III. The serotypes of the isolates in terms of resistance for antibiotics are presented in Table 2. The highest resistance rate to erythromycin and clindamycin was found in serotype III and V. The highest resistance rate to tetracycline was in serotype la and III. MIC ${ }_{50}, \mathrm{MIC}_{90}$ values and MIC ranges of the strains for GBS are shown in Table 3. All the strains were found to be susceptible to penicillin $G$ and ceftriaxone. According to the D-test results, constitutional $\mathrm{MLS}_{\mathrm{B}}$ phenotype was found in 15 out of 19 (79\%) erythromycin-resistant GBS strains; inducible $\mathrm{MLS}_{\mathrm{B}}$ phenotype was found in $2(10.5 \%)$, and efflux phenotype was found in $2(10.5 \%)$. When the resistance mechanisms of the isolates for macrolide were assessed according to serotype distribution, the structural and inducible $\mathrm{MLS}_{\mathrm{B}}$ resistance phenotype was seen mostly in serotype III and V, whereas the efflux phenotype was seen only in serotype III.

\section{Discussion}

S. agalactiae is one of the most important pathogens in newborn sepsis and meningitis, and has a high mortality and morbidity in spite of the current antibiotic treatment in new- born. Pregnancy-related GBS infections cause serious infections both in the mother and the neonate during labor or the early postpartum period. The mortality rate for newborns due to GBS infection during the first three months after birth is 0.5-3 per 1000 live births (1). The invasive $S$. agalactiae infections in adults is in the form of puerperal infections or infections with underlying immune-compromising conditions such as alcoholism, diabetes mellitus, malignancy or HIV. In adults with these conditions, the infection spectrum consists of pneumonia, bacteremia, endocarditis, urinary system infection, skin and soft tissue infections, and osteomyelitis (7). Serotype definition in these strains can be made by various methods including immunoprecipitation, enzyme immunoassay, co-agglutination, immunoelectrophoresis, capillary precipitation, latex agglutination, fluorescence microscopy and inhibition ELISA. Molecular typing methods can be used in the epidemiological studies; however, they are not chosen for serotype definition as they are very expensive and time-consuming. We used the latex agglutination method. Nine capsular polysaccharide serotypes of GBS have been known so far: serotype la, lb, II-VIII. Based on the US and European data, $86 \%-90 \%$ of the clinical isolates are serotype la, II, III and V $(8,9)$. Serotype VI and VIII were reported as the most common GBS strains in Japan $(10,11)$. Recently, Zeng et al. (12) developed separate multiplex PCR-based reverse line blot-hybridization assays to identify molecular serotypes of GBS and isolated mainly the serotypes III, la, V, Ib and II. In Chile and Senegal, the most commonly isolated serotypes were III, Ib, V and la in pregnant women and neonates using the latex agglutination method $(13,14)$. In Turkey, while the most commonly isolated serotypes were la, II, III in Istanbul (15), serotype III, $1 \mathrm{~b}$ and $\mathrm{V}$ were the most common serotypes in the Tokat region (16). We could not find any strain of serotype VII and VIII, and the most common serotypes in our study were serotype la (36\%), III (30.5\%), II (13\%), V (13\%), Ib (3\%), IV (1.5\%), and VI (1.5\%), respectively. Two isolates could not be serotyped with the available antisera.

Intrapartum penicillin is recommended for prevention of perinatal infections, as there is a risk of infection transmission from the GBS-colonized mother to the neonate. Erythromycin

Table 1. Serotype distribution of $S$. agalactiae strains according to the isolation sites ( $\mathrm{n}: 131)$

\begin{tabular}{|c|c|c|c|c|c|}
\hline Serotype & $\begin{array}{l}\text { Urinary tract } \\
\text { infection } \\
n(\%)\end{array}$ & $\begin{array}{c}\text { Soft tissue } \\
\text { infection } \\
n(\%)\end{array}$ & $\begin{array}{c}\text { Bloodstream } \\
\text { infection } \\
n(\%)\end{array}$ & $\begin{array}{c}\text { Vaginal } \\
\text { colonization } \\
\text { n (\%) }\end{array}$ & $\begin{array}{l}\text { Total } \\
\text { n (\%) }\end{array}$ \\
\hline la & $33(33.4)$ & $9(45)$ & $4(40)$ & $1(50)$ & $47(36)$ \\
\hline lb & $2(2)$ & $2(10)$ & - & - & $4(3)$ \\
\hline II & $9(9.1)$ & $5(25)$ & $2(20)$ & $1(50)$ & $17(13)$ \\
\hline III & $39(39.4)$ & - & $1(10)$ & - & $40(30.5)$ \\
\hline IV & $1(1)$ & $1(5)$ & - & - & $2(1.5)$ \\
\hline $\mathrm{V}$ & $13(13.1)$ & $2(10)$ & $2(20)$ & - & 17 (13) \\
\hline VI & $1(1)$ & - & $1(10)$ & - & $2(1.5)$ \\
\hline VII & - & - & - & - & $0(0)$ \\
\hline VIII & - & - & - & - & $0(0)$ \\
\hline Nontypable & $1(1)$ & $1(5)$ & - & - & $2(1.5)$ \\
\hline
\end{tabular}


Table 2. Serotype distribution of resistant $S$. agalactiae strains ( $\mathrm{n}: 131)$

\begin{tabular}{|lcccc|}
\hline Serotype & Number & \multicolumn{4}{c|}{ Antibiotic } \\
\cline { 3 - 5 } & & Erythromycin & Clindamycin & Tetracycline \\
& & n (\%) & n (\%) & n (\%) \\
\hline Ia & 47 & $1(2.1 \%)$ & $1(2.1 \%)$ & $40(85 \%)$ \\
Ib & 4 & - & - & $4(100 \%)$ \\
II & 17 & $1(5.8 \%)$ & $1(5.8 \%)$ & $14(82.3 \%)$ \\
IV & 40 & $14(35 \%)$ & $12(30 \%)$ & $39(97.5 \%)$ \\
V & 2 & - & - & $2(100 \%)$ \\
VI & 17 & $3(17.6 \%)$ & $3(17.6)$ & $16(94 \%)$ \\
VII & 2 & - & - & $2(100 \%)$ \\
VIII & 0 & - & - & - \\
Nontypable & 2 & - & - & - \\
Total & 131 & $19(14.5)$ & $17(13)$ & $118(90)$ \\
\hline
\end{tabular}

Table 3. MIC ranges, $\mathrm{MIC}_{50}$ and $\mathrm{MIC}_{90}$ values of $\mathrm{S}$. agalactiae strains to penicillin $G$ and ceftriaxone (n:131)

\begin{tabular}{|lccc|}
\hline Antibiotic & \multicolumn{3}{c|}{ MIC $(\boldsymbol{\mu g} / \mathrm{ml})$} \\
& MIC range & MIC $_{50}$ & MIC $_{90}$ \\
\hline Penicillin G & $<0.01-0.06$ & $<0.01$ & 0.03 \\
Ceftriaxone & $<0.01-0.25$ & 0.03 & 0.03 \\
\hline
\end{tabular}

and clindamycin are preferred in the event of penicillin allergy. Although there is no reported penicillin resistance in GBS isolates responsible for the neonatal invasive infections in recent studies, resistance to erythromycin was reported as $7 \%-46 \%$, and to clindamycin as $3 \%-43 \%(17,18)$. All S. agalactiae isolates reported from Turkey were found to be susceptible to penicillin, ampicillin, vancomycin, ceftriaxone, chlorampheni$\mathrm{col}$ and ofloxacine. The rates of resistance to erythromycin, clindamycin and tetracycline were found to be $7 \%-24.5 \%$, $9 \%-19.4 \%$, and $81.6 \%-91 \%$, respectively $(15,16,19,20)$. In our study, while all GBS isolates were found to be susceptible to penicillin, ceftriaxone and vancomycin, $14.5 \%$ were found to be resistant to erythromycin and $13 \%$ were found to be resistant to clindamycin. In a previous study in the same region, erythromycin resistance was reported as $7 \%$ (19). Therefore, it was seen that erythromycin resistance in our region had doubled. It was reported that ermB, ermA, ermTR and mefA genes were responsible for erythromycin and clindamycin resistance $(18,21,22)$. As the PCR method was not used in this study, macrolide resistance genes could not be identified; however, the D-test was performed on the resistant strains to define the resistance phenotypes. The structural resistance was found to be $79 \%$, the inducible resistance $10.5 \%$ and the efflux-related resistance $10.5 \%$. It was reported that erythromycin and clindamycin resistance was more prevalent in serotypes V and III (22). We also found erythromycin and clindamycin resistance to be more prevalent in serotypes III and V. Tetracycline was the antimicrobial agent with the highest rate
(90\%) of resistance among the tested antibiotics. Similar results were reported in other studies. Tetracycline resistance is considered to be related to the tetM gene (22).

In conclusion, there is no problem regarding resistance to penicillin G, ceftriaxone and vancomycin in GBS strains in our region, and penicillin is still the first choice of treatment in GBS infections. As it was reported that the resistance rates of strains for erythromycin and clindamycin is increasing, these antibiotics should not be preferred, except for beta-lactam allergy. Studies showed that long-term prevention can be maintained with the use of conjugated polysaccharide vaccine for GBS-related maternal infections, still-births and neonatal infections (23). Further epidemiological studies on serotype distribution are required to assess the value of the vaccine in our country.

\section{Conflict of Interest}

No conflict of interest was declared by the authors.

\section{References}

1. Schuchat A. Group B streptococcus. Lancet 1999;353:51-6. [CrossRef]

2. Regan JA, Klebanoff MA, Nugent RP, Eschenbach DA, Blackwelder WC, Lou Y, et al. Colonization with group B streptococci in pregnancy and adverse outcome. VIP Study Group. Am J Obstet Gynecol 1996;174:1354-60. [CrossRef]

3. Farley MM. Group B streptococcal disease in non pregnant adults. Clin Infect Dis 2001;33:556-61. [CrossRef]

4. Clinical and Laboratory Standards Institute. Methods for Dilution Antimicrobial Susceptibility Tests for Bacteria That Grow Aerobically; Approved Standard- Eighth Edition. CLSI document M07A8. Clinical and Laboratory Standards Institute, Wayne, Pennsylvania, 2009.

5. Clinical and Laboratory Standards Institute. Performance standards for Antimicrobial Susceptibility Testing; Nineteenth Informational Supplement. CLSI document M100-S19. Clinical and Laboratory Standards Institute, Wayne, Pennsylvania, 2009.

6. Seppala H, Nissinen A, Yu Q, Huovinen P. Three different phenotypes of erythromycin-resistant Streptococcus pyogenes in Finland. J Antimicrob Chemother 1993;32:885-91. [CrossRef]

7. Başustaoğlu A. Klinik Mikrobiyoloji (Manual of Clinical Microbiology). 9.baskı.Ankara, Atlas Yayınları,2009:415.

8. Campbell JR, Hillier SL, Krohn MA, Ferrieri P, Zaleznik DF, et al. Group B streptococcal colonization and serotype-specific immunity in pregnant women at delivery. Obstet Gynecol 2000;96:498-503. [CrossRef]

9. Flugge K, Supper S, Siedler A, Berner R. Serotype distribution of invasive group $B$ streptococcal isolates in infants: results from a nationwide active laboratory surveillance study over 2 years in Germany. Clin Infect Dis 2005;40:760-3. [CrossRef]

10. Matsubara K, Nishiyama Y, Katayama K, Yamamoto G, Sugiyama $M$, Murai T, et al. Change of antimicrobial susceptibility of group B solated cci over 15 years in Japan. J Antimicrob Chemother 2001;48: 579-82. [CrossRef]

11. Terakubo $S$, Ichiman $Y$, Takemura $H$, Yamamoto $H$, Shimada J, Nakashima H. Serotypes and antibody levels of group B streptococci in pregnant women. Kansenshogaku Zasshi 2003;77:121-6.

12. Zeng X, Kong F, Morgan J, Gilbert GL. Evaluation of a multiplex PCR-based reverse line blot-hybridization assay for identification of serotype and surface protein antigens of Streptococcus agalactiae. J Clin Microbiol 2006;44:3822-5. [CrossRef] 
13. Cissed MF, Camara B, Diaw CF, Ba M. Serotypes and antibiotypes of Streptococcus agalactiae strains solated in Dakar. Med Mal Infect 2003;33:318-22. [CrossRef]

14. Martinez MA, Ovalle A, Duran C, Reid I, Urriola G, Garay B, et al. Serotypes and antimicrobial susceptibility of Streptococcus agalactiae. Rev Med Chil 2004;132:549-55.

15. Eren A, Kucukercan M, Oguzoglu N, Unal N, Karateke A. The carriage of group $B$ streptococci in Turkish pregnant women and its transmission rate in newborns and serotype distribution. The Turk J Pediatr 2005;47:28-33.

16. Yenisehirli G, Bulut $Y$, Demirturk F, Caliskan AC. Antimicrobial susceptibilities and serotype distribution of Streptococcus agalactiae strains isolated from pregnant women. Mikrobiyol Bul 2006;40:155-60.

17. Motlava J, Strakova L, Urbaskova P, Sak P, Sever T. Vaginal \& rectal carriage of Streptococcus agalactiae in the Czech Republic: incidence, serotypes distribution and susceptibility to antibiotics. Indian J Med Res 2004;119:84-7.
18. Hsueh PR, Teng LJ, Lee LN, Ho SW, Yang PC, Luh KT. High incidence of erythromycin resistance among clinical isolates of Streptococcus agalactiae in Taiwan. Antimicrob Agents Chemother 2001;45:3205-8. [CrossRef]

19. Esel D, Karaca N, Telli M, Sumerkan B. Klinik örneklerden izole edilen Streptococcus agalactiae suslarinda duyarlilik. Ankem Derg 2001;15:678-82

20. Arisoy AS, Altinisik B, Tunger $O$, Kurutepe $S$, Ispahi $C$. Maternal carriage and antimicrobial resistance profile of group B Streptococcus. Infection 2003;31:244-6.

21. Uh Y, Jang IH, Hwang GY, Lee MK, Yoon KJ, Kim HY. Serotypes and genotypes of erythromycin-resistant group $B$ streptococci in Korea. J Clin Microbiol 2004;42:3306-8. [CrossRef]

22. Dogan B, Schukken YH, Santisteban C, Boor KJ. Distribution of serotypes and antimicrobial resistance genes among Streptococcus agalactiae isolates from bovine and human hosts. J Clin Microbiol 2005;43:5899-906. [CrossRef]

23. Baker CJ, Edwards MS. Group B streptococcal conjugate vaccines. Arch Dis Child 2003;88:375-8. [CrossRef] 